\title{
Status of Large Cardamom (Amomum subulatum) among the Major Crops in Sikkim, India
}

\author{
Smriti Subba* and Souvik Ghosh \\ Department of Agricultural Extension, Institute of Agriculture, Visva-Bharati University, \\ Sriniketan, West Bengal - 731236, India \\ *Corresponding author
}

\section{A B S T R A C T}

\begin{tabular}{|l|}
\hline Ke y w o r d s \\
Large Cardamom, \\
$\begin{array}{l}\text { Ginger, Maize, Paddy, } \\
\text { Area, Production, } \\
\text { productivity }\end{array}$ \\
\hline Article Info \\
\hline $\begin{array}{l}\text { Accepted: } \\
\text { 04 September } 2017 \\
\text { Available Online: } \\
\text { 10 November } 2017\end{array}$ \\
\hline
\end{tabular}

The present study was undertaken to assess status of Large Cardamom (Amomum subulatum) among major crops in Sikkim. The study was measured based on area, production and productivity including cumulative annual exponential growth rate (CAEGR) over a time period from 2003-2015.The study revealed positive growth rate (0.36) of the area under large cardamom crop. However, the production showed a negative growth rate $(-1.68)$ that may be attributed to some viral disease complex, nutritional deficiencies factors and inadequate management. Productivity of large cardamom depicted a positive growth rate $(0.51)$. In contrast, growth rate of the area under ginger was found 6.27 and that of production and productivity was found 6.63 and 2.98 , respectively. Growth rate of area, production and productivity of paddy was found 0.70, 1.89 and 1.20, respectively. Growth rate of area under maize was found negative $(-2.72)$ and the same was in case of production.

\section{Introduction}

India is the largest producer of Large Cardamom with 54 percent share in world production. Sikkim produces 80 percent of India's Large Cardamom, which enjoys a high value export market in Pakistan being the single largest market, Singapore and MiddleEast (Economic Survey of Sikkim 2006-07). Export of Large Cardamom increased during the 1980s. India is the largest market for Large Cardamom produced by Nepal and Bhutan as well. The major markets in India are Amritsar, Kolkata, Delhi, Guwahati and Kanpur. It is also cultivated in parts of Uttaranchal and in some other North-eastern States. Large Cardamom has played a vital role in the economy of hilly regions as it is having export potential and contributes significantly in the state's economy in terms of direct or indirect employment and income generation. Large Cardamom (Amomum subulatum) is the most important cash crop in the eastern Himalayan region including Sikkim and the Darjeeling hills in India, the eastern part of Nepal, and southern Bhutan (Sharma et al., 2000). It is native to Sikkim (Sharma, 2000), known as 'Queen of Spices' (Maitra, 2007) and belongs to family Zingibereaceae and order Scitaminae (Bisht et al., 2011). About $80 \%$ of the people are directly or indirectly dependent on scarce land resources for their livelihood. Sikkim has the largest area and the highest production of 
Large Cardamom in India. It is cultivated in all districts of Sikkim and has Large Cardamom plantations on their farm. The gross income of households was almost double in Large Cardamom-dominated systems, compared to traditional mixed-forest systems in Sikkim Himalaya (Sharma et al., 2000). The principal crops of the state are maize, rice. Among North Eastern States Ginger of Sikkim ranks 3rd in area and 5th in production as well as productivity at the regional level (NEC, 2002).

The ginger of Sikkim is also of a good quality and has export prospects (Economic Survey of Sikkim 2006-07). It is the second most important cash / spice crop, the first being Large Cardamom. Large Cardamom cultivation has played a vital role in the economy of hilly regions such that it is a purely exporting commodity for earning foreign currency and also mentioned that the net income from Large Cardamom is higher than from other cash crops throughout the period.

The income from the Large Cardamom has been substantially higher than for other livelihood options (Sharma 1999). Large Cardamom farming has been contributing in fulfilling their basic needs with a provision of easy availability of loan, better houses and better education. In addition to this they were now in position to spend money on medicine, food, cloth, religious matter and payment of loan. About $3.8 \%$ of the respondents spend above Rs 60,000 annually to provide quality education for their children, which was a hopeful symptom of increment in the literacy rate (Yadav 2013). Earlier price of dry capsules were sold at Rs.700-750 per kg. which has been increased by Rs. 1350/- per $\mathrm{kg}$ of dry capsules through adoption of scientific cultivation of Large Cardamom which means there is a huge scope of livelihood improvement of rural people in
Sikkim and also the productivity of Large Cardamom can be increased by around 70 to $100 \mathrm{~kg} / \mathrm{ha}$, (ICRI, RRS, Spices Board of Tadong 2010). Many farmers of Sikkim reported that the production of both major food crops as well as of cash crops has gone down significantly Portel (2014). Sikkim is also fast becoming known in India for its organic farming, and organic Large Cardamom has a potentially strong international market (FSADD and HCDD 2012). For more than a decade now (2004 onwards), however, more than $60 \%$ of the cardamom plantations in Sikkim have become barely productive, resulting in a tremendous decline in cultivated area as well as total production in the state (DESME 2002, 2005, 2006, 2010; HCCDD 2010). Hence, the present study highlights the potentials of Large Cardamom then Ginger, paddy and Maize. Thus, it would help to increase the production area, production and bridge the yield gap between the time series for future sustainability and viability to achieve opportunities for the sector in the state.

On this backdrop, an attempt was made to assess spatio-temporal variation in area, production and productivity of large cardamom in comparison to other major crops like paddy, maize, and ginger in Sikkim.

\section{Materials and Methods}

The present study was carried out based on secondary data for four districts of Sikkim. The secondary time series data regarding area, production and productivity of large cardamom and different major crops (ginger, paddy, and maize) were considered for the period from 2003 to 2015 from various published data sources (State Profile of Sikkim, 2010-2011, State Annual Report2009, 2010, 2011, 2012-13, www.sikkimagrisnet.org, Economic Survey of Sikkim of different years, etc.). 
Cumulative annual exponential growth rate (CAEGR) was calculated for area, production and productivity of different crops by using the following formula:

$\log \mathrm{Y}_{\mathrm{it}}=\alpha+\beta \mathrm{t}$

In case of parameters under agriculture,

$\mathrm{Y}_{\mathrm{it}}=$ value of the ithparameter considered under agriculture $\mathrm{t}$ time $\mathrm{t}(\mathrm{i}=1,2, \ldots, \mathrm{n})$

$\mathrm{t}=$ time in years;

$\alpha, \beta=$ parameters; and,

$\beta$ gives the annual exponential rate of growth of area and its fluctuation around the trend can be estimated by using standard error.

\section{Results and Discussion}

The result of the present study shows the spatio temporal variation in status of large cardamom (Amomum subulatum) among the major crops, which are presented below:

\section{Land use pattern in Sikkim}

The differential land use pattern in Sikkim over a period of 2003-2015 is presented in Figure 1. Net sown area out of cultivable area has not changed much.

However, net irrigated area has increased from $6 \%$ to $24 \%$ during the period under study. Gross irrigated area has increased from $11 \%$ to $25 \%$ during the same period.

Therefore, an improvement in land use pattern with respect to the agricultural practices is witnessed in the state of Sikkim. This is further established from the improvement in cropping intensity from $155 \%$ to $199 \%$ as depicted in the Figure 2. This has showed a mark improvement since the year 20019-10.
Area, production and productivity of major crops in Sikkim

In India, cardamom is a native to the tropical areas of the world but some spice can also be cultivated in cooler areas of the world. The area and production of large cardamom in India and Sikkim state from period of 20032015 is given in Table 1. The area under large cardamom has increased from 95.60 thousand ha to 99.20 thousand ha in India while that has decreased from 26.73 thousand ha to 23.41 thousand ha in Sikkim. Large Cardamom area in Sikkim was 26.73 thousand ha with the production of 5.10 thousand tonnes and became the largest producer in the world. However, with the consistent decline in plantation area after 2004, production declined to 2.74 thousand tonnes in 2008, and India dropped to second place, after Nepal. Production gained a little momentum from 2008 to 2013, owing to increased awareness, farmers' innovations and motivation, and the government's provision of extension services aiming to raise the production area (HCCDD 2011). Accordingly, the large-cardamom production area in 2013 was $14 \%$ greater than in 2007.

\section{Large cardamom}

Large cardamom is the traditional spice crop which was in its glory during the mid and late eighties. Decline set in after nineties the cause of which is attributed to some disease complex, nutritional factors and inadequate management. The decline has had wide ranging ramifications disorienting agrarian economy and upsetting cropping patterns. The area of large cardamom has increased to 26.73 thousand ha, as a result of the area expansion mission initiated by the Food Security and Agriculture Department and the Horticulture and Cash Crop Development Department, Government of Sikkim (200304). The total production of Large Cardamom 
increased to 3.31 thousand tonnes by 2007 2008. Similarly, the yield also decreased to the bare minimum $(219 \mathrm{~kg} / \mathrm{ha})$ during $2007-$ 08 , after that in 2010 , started improving from $230 \mathrm{~kg} / \mathrm{ha}$ and reached to $237 \mathrm{~kg} / \mathrm{ha}$ during 2012-2013.

\section{Ginger}

Ginger is another cash crop grown in the state after large cardamom. It is locally called Adhua. It can be seen from Figure 1 that the area under ginger cultivation was 6.47 thousand ha in 2003-2004 and increased to 9.84 thousand ha in 2014-2015. The production has showed fluctuations over the study period; however it has increased from 33.53 thousand tonnes to 62.56 thousand tonnes. This improvement in the production was owing to the increase in the area under the crop and proper management practices with organic technique during the later period (SIKKIM towards Fully Organic State by 2015, ed. 2012, published by FS\&ADD and H\&CCDD, Government of Sikkim).

On the other hand, the productivity of the ginger shows continuous positive growth trends from $5186 \mathrm{~kg} / \mathrm{ha}$ to $8979 \mathrm{~kg} / \mathrm{ha}$ in 2014-2015 presented in Figure 3.

Fig.1 Land use pattern in Sikkim during the period of 2003-2015

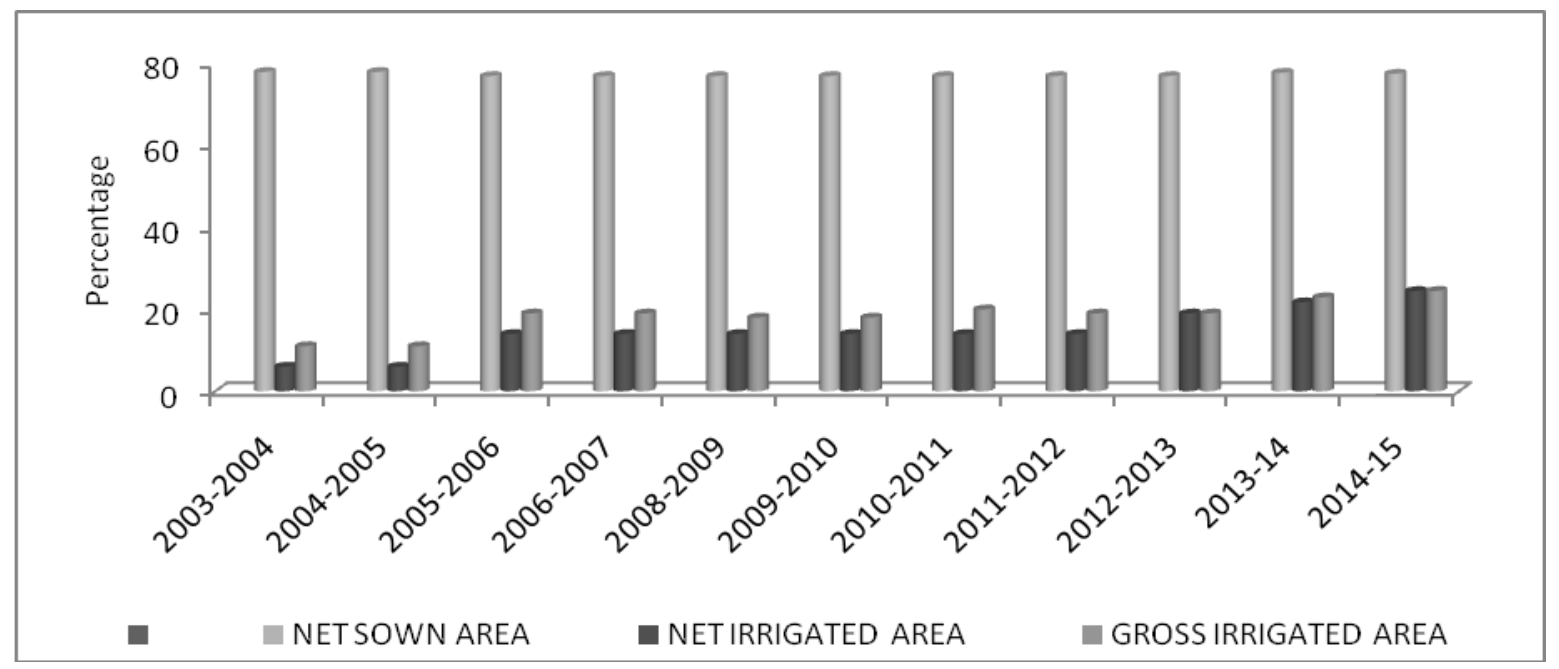

Fig.2 Differential cropping intensity in Sikkim during the period of 2003-2015

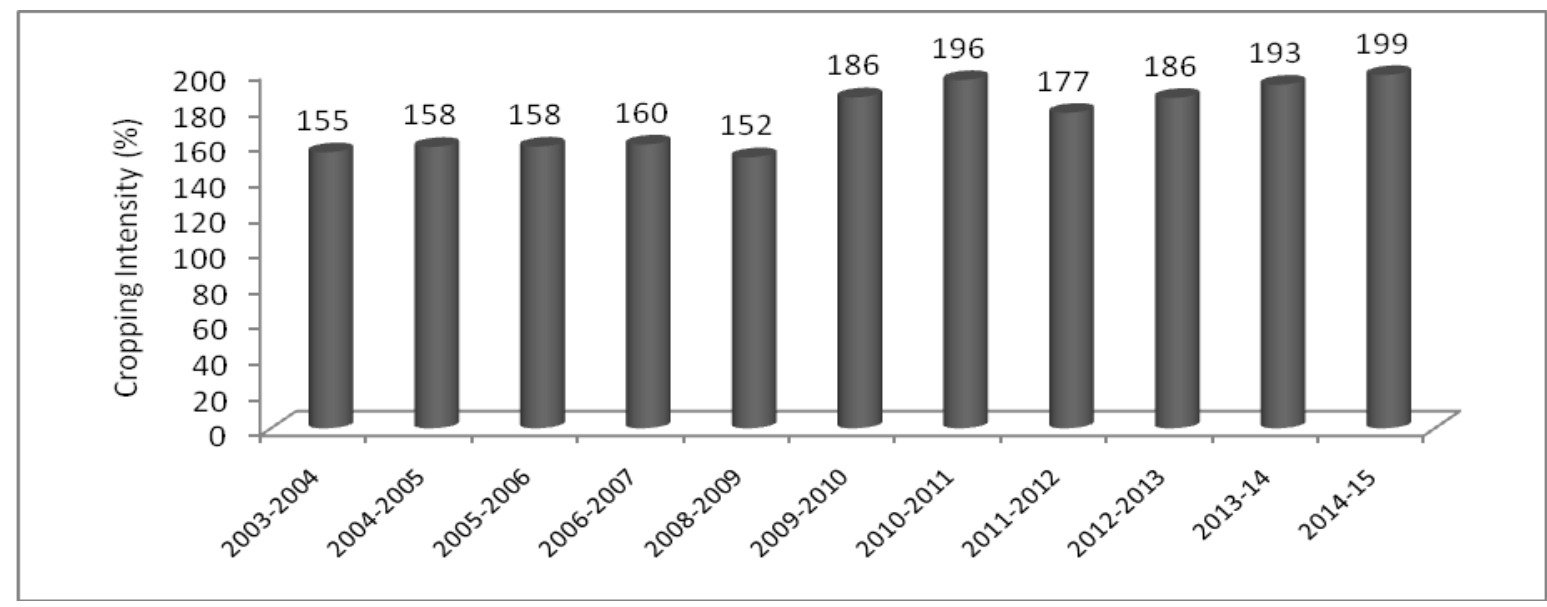


Fig.3 Differential area under different major crops of Sikkim during 2003-2015

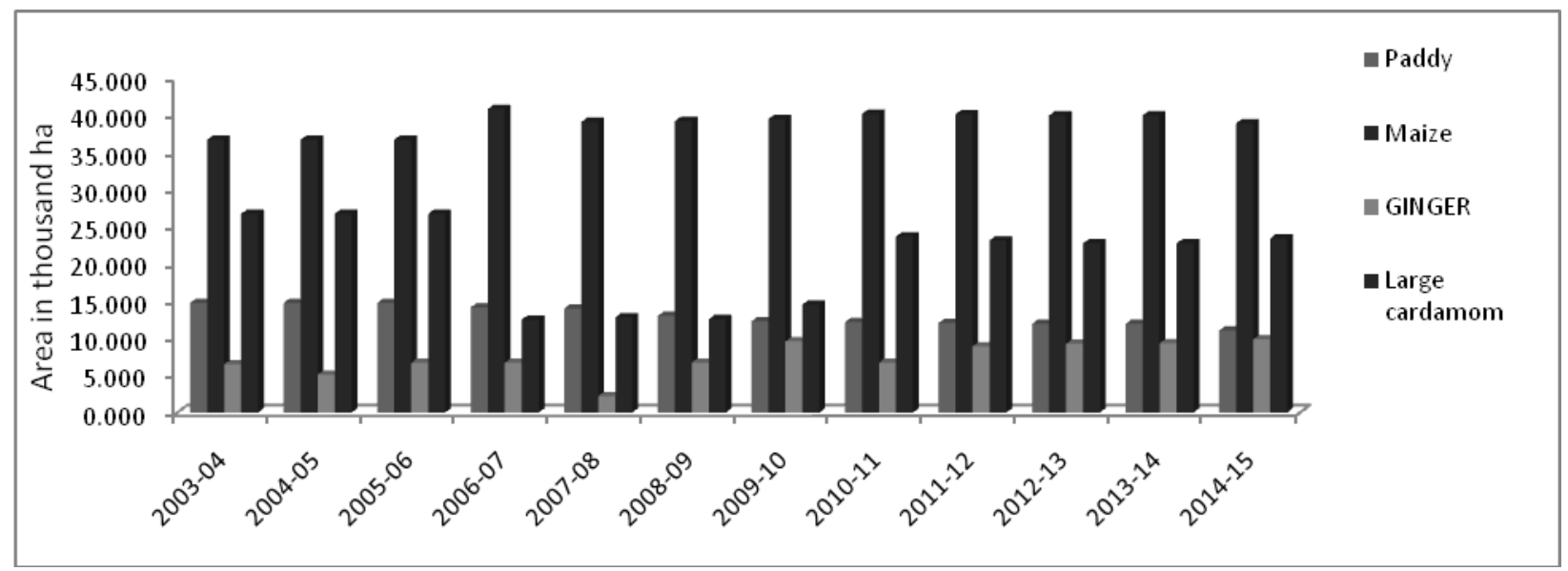

Fig.4 Production of different major crops of Sikkim during 2003-2015

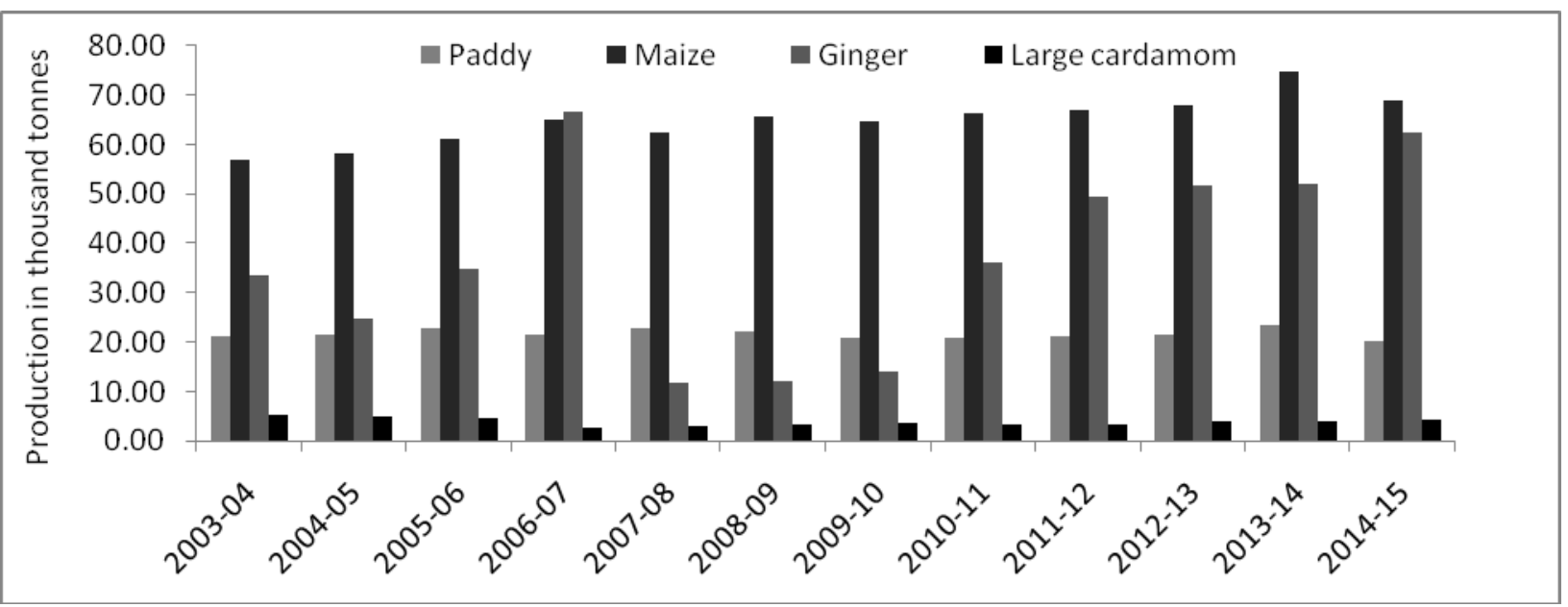

Fig.5 Productivity of different major crops of Sikkim during 2003-2015

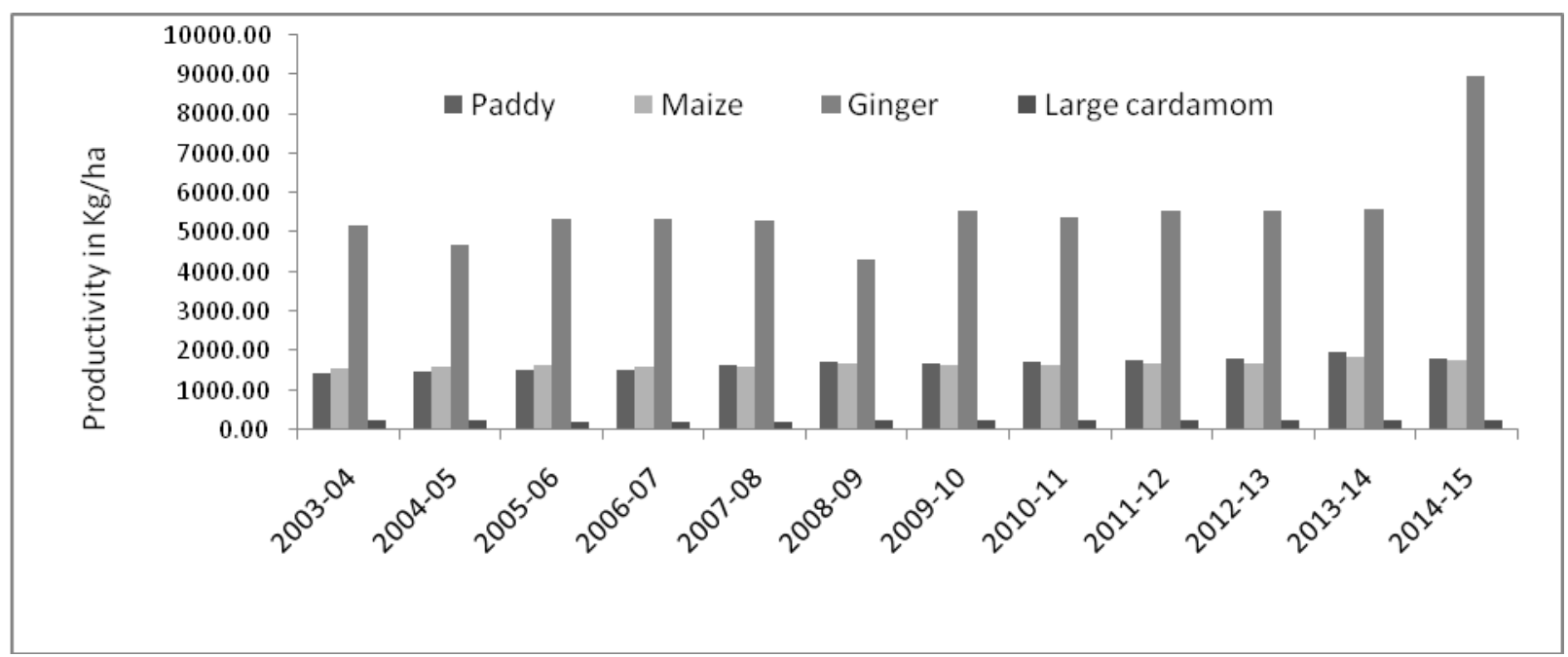


Fig.6 Growth rate of the area under different crops in Sikkim

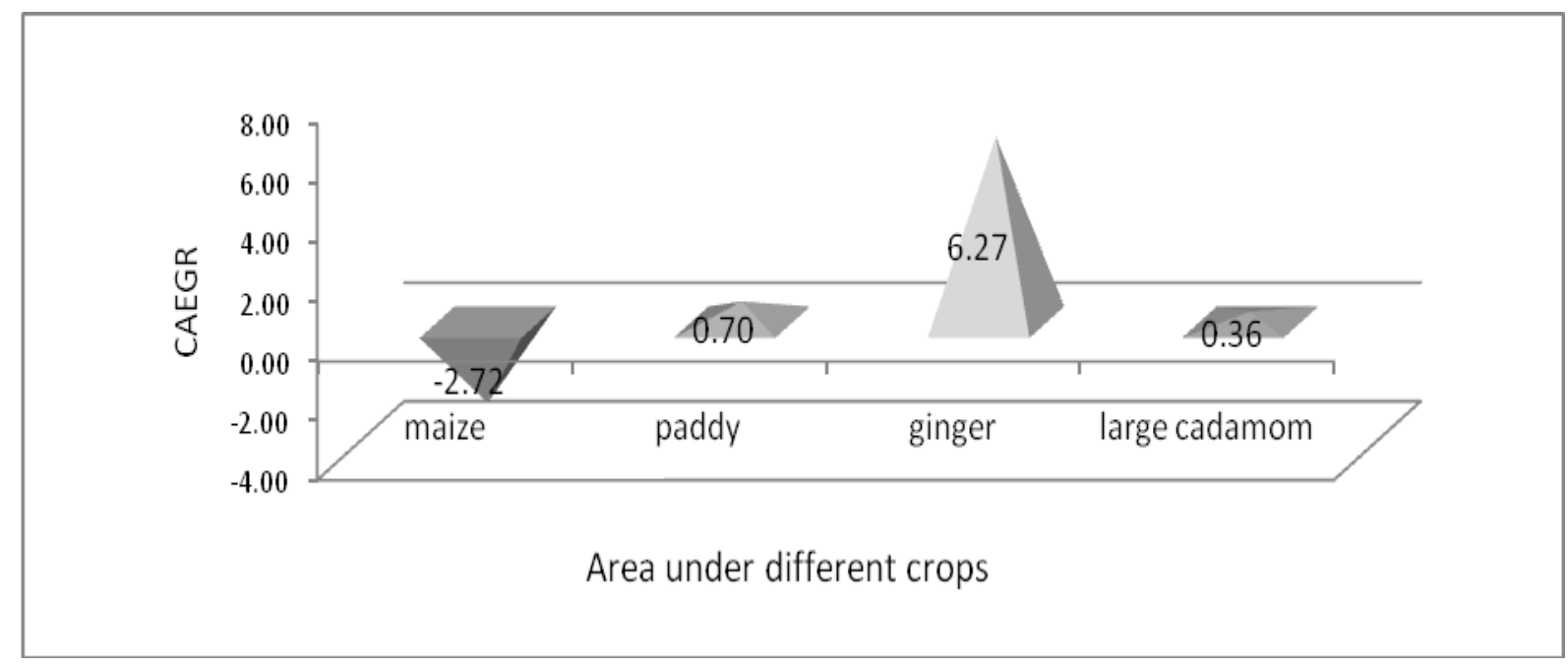

Fig.7 Growth rate of the production of different crops in Sikkim

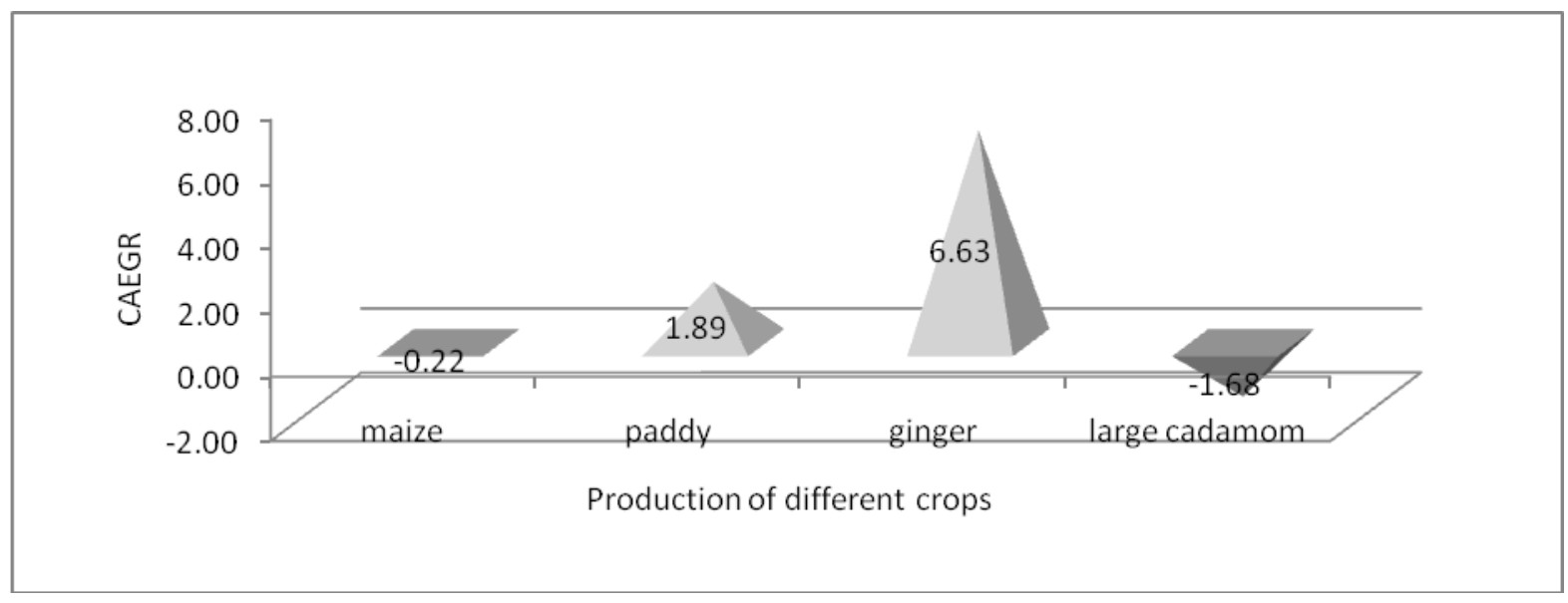

Fig.8 Growth rate of the productivity of different crops in Sikkim

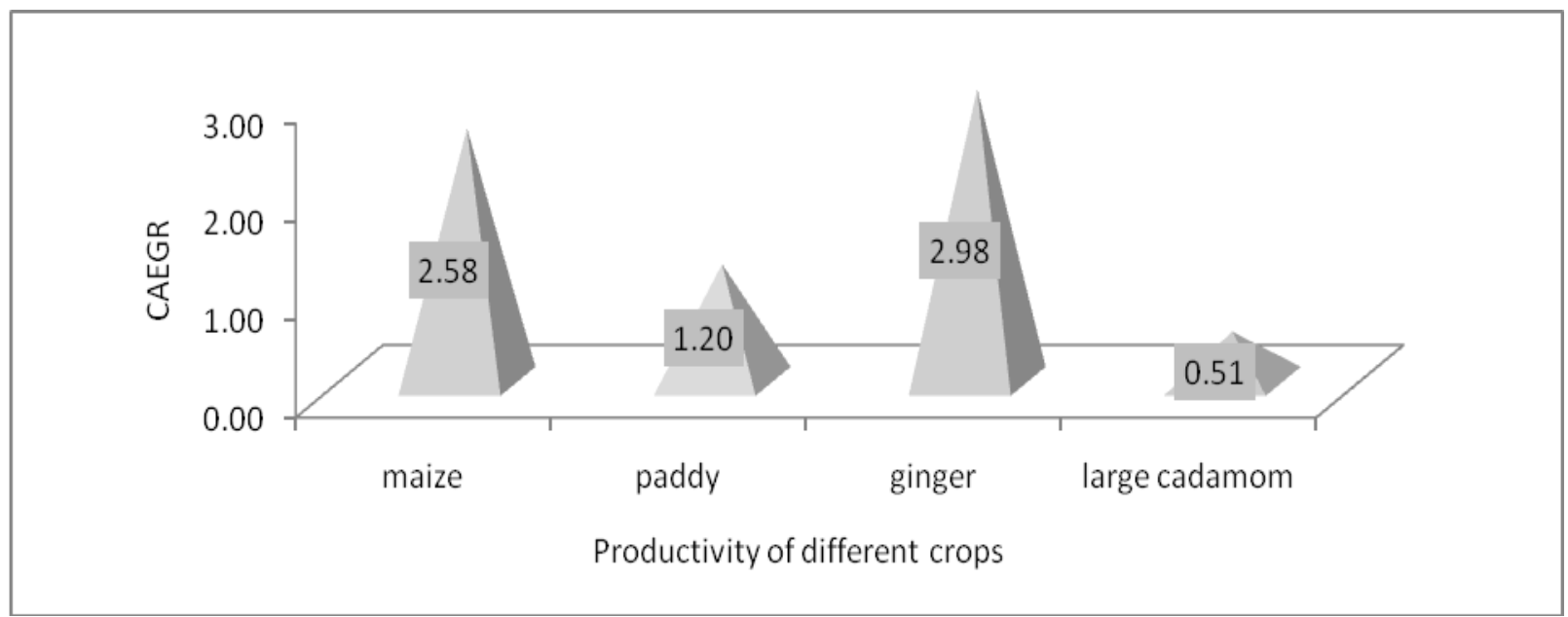


Table.1 Area and production of large cardamom within India and Sikkim

\begin{tabular}{|l|l|c|c|c|c|}
\hline \multirow{2}{*}{$\begin{array}{l}\text { Sl. } \\
\text { No. }\end{array}$} & \multirow{2}{*}{ Year } & \multicolumn{2}{|c|}{ INDIA } & \multicolumn{2}{|c|}{ SIKKIM } \\
\cline { 3 - 6 } & & $\begin{array}{c}\text { Area } \\
\mathbf{9 0 0 0} \text { ha })\end{array}$ & $\begin{array}{c}\text { Production } \\
\mathbf{( 0 0 0} \text { tonnes })\end{array}$ & $\begin{array}{c}\text { Area } \\
(\mathbf{0 0 0} \text { ha) }\end{array}$ & $\begin{array}{c}\text { Production } \\
(\mathbf{0 0 0} \text { tonnes })\end{array}$ \\
\hline 1. & $2003-04$ & 95.60 & 16.70 & 26.73 & 5.10 \\
\hline 2. & $2004-05$ & 95.20 & 16.90 & 26.73 & 4.98 \\
\hline 3. & $2005-06$ & 95.80 & 17.80 & 26.73 & 4.48 \\
\hline 4. & $2006-07$ & 98.20 & 15.70 & 12.50 & 2.74 \\
\hline 5. & $2007-08$ & 81.80 & 13.40 & 12.80 & 2.90 \\
\hline 6. & $2008-09$ & 91.99 & 15.45 & 12.56 & 3.31 \\
\hline 7. & $2009-10$ & 90.20 & 15.72 & 14.52 & 3.47 \\
\hline 8. & $2010-11$ & 87.00 & 16.00 & 23.67 & 3.31 \\
\hline 9. & $2010-12$ & 89.00 & 15.80 & 23.15 & 3.23 \\
\hline 10. & $2012-13$ & 92.40 & 18.40 & 22.75 & 3.48 \\
\hline 11. & $2013-14$ & 99.20 & 20.70 & 22.75 & 3.74 \\
\hline 12. & $2014-15$ & 99.20 & 20.72 & 23.41 & 4.08 \\
\hline
\end{tabular}

Source: Agriculture Statistics at a Glance 2014, Ministry of Agriculture GOI. Annual Reports, Food Security and Agriculture Development Department, Government of Sikkim, 2009-10,2010-11,2012-12 and 2013-2015.

\section{Paddy}

Paddy is most important staple cereal crop of Sikkim grown in all places having warm and humid climate with shallow water. The residual of the crop (Paraal in local language) is the main source of animal fodder. The share of paddy as the main food item, in the total food production has been hardly $20 \%$. The per capita availability of paddy in the state is $158 \mathrm{gms} /$ day which is far below the National average of 417 gm during 2001-02 (Economic Survey of Sikkim, 2006-07). It shows that the State is deficit in paddy production which is the staple food of the State; therefore, the State is dependent on import of rice from outside the State. The trend of area under the paddy production is declining slowly. From Figure 1 it is evident that area under paddy crop was 14.74 thousand ha in 2003-04 which has decreased to 11.04 thousand ha in 201415. It shows the substitution of cash crops for food crops. The production increased from 21.19 thousand tonnes to 23.44 thousand tonnes in 2013-14 is presented in Figure 2. However, the productivity increased from $1437 \mathrm{~kg}$ per ha to $1966.44 \mathrm{~kg} / \mathrm{ha}$ in $2014-$ 2015 is presented in Figure 3.

\section{Maize}

Maize is part of the staple food item in Sikkim; its production contributes over 50 percent of the total food grains production in the State. The crop is largely used as animal fodder. Figure 1 depicts that the area under maize was increased from 36.70 thousand ha in 2003-04 to 40.85 thousand ha in 2006-07. Thereafter, there was a decline and it was increased again in 2010-2012 with an area of 40.10 thousand ha.

Hence, the production of maize increased to 74.75 thousand tonnes from 57.05 thousand tonnes in 2003-04 as presented in Figure 2. Here it showed that the production of maize is improved over a period of time. The improvement in production was owing to the increase in the area through proper management of the crop with organic technique during the later period (SIKKIM towards Fully Organic State by 2015, ed. 2012, published by FS\&ADD and H\&CCDD, Government of Sikkim). On the other hand, Figure 3 represents the productivity of maize showed an improvement from $1664.85 \mathrm{~kg} / \mathrm{ha}$ in $2005-2006$ to $1870.15 \mathrm{~kg} / \mathrm{ha}$ in $2013-2014$. 
The growth rate of area, production and productivity of the major crops of Sikkim in comparison to large cardamom were calculated for the period of 2003-2015 and the same are depicted through Figures 4, 5 and 6, respectively. It is revealed that the growth rate of area under large cardamom was found positive (0.36), while the growth rate of maize was negative $(-2.72)$. The area under paddy and ginger showed positive growth rate of 0.70 and 6.27, respectively (Fig. 4). This may be due to the result of the area expansion mission initiated by the Food Security and Agriculture Department and the Horticulture and Cash Crop Development Department, Government of Sikkim (2003-2004). Large cardamom production showed a negative growth rate of -1.68 as shown in Figure 5 . This may be attributed to the fact to some viral disease complex, nutritional deficiencies factors and inadequate management. However, as the farmers can sell their produce in auction plan, they have been able to get nearly Rs. 1620 per $\mathrm{kg}$ as compared to the other crops (Sikkimnow.blogsspot.in. 2014). The growth rate of productivity of large cardamom was found positive (0.51) due to improved package of practices being followed by the farmers having higher motivation level and the provision of extension services by agencies aiming to raise the area and productivity of the large cardamom crop. Another important cash crop of the Sikkim is ginger. Figure 4 showed that area under ginger cultivation was had positive growth rate (6.27). Similarly, the production and productivity also depicted positive growth rates (6.63 and 2.98) as given in Figures 5 and 6. This may be due to the management practices with organic technique during the later period of the timeframe considered for present study (SIKKIM towards Fully Organic State by 2015, ed. 2012, published by FS\&ADD and H\&CCDD, Government of Sikkim). Paddy production was found with a positive growth rate (1.89). The productivity was found to be improved with a growth rate of 1.20 (Fig. 5) although the area of paddy has declined showing a growth rate of 0.70 . Both are and production of maize have also showed negative growth rates (Figs. 4 and 5). Both the maize and paddy crops are being substituted by cash crops like ginger and large cardamom.

The study revealed the status of large cardamom and other major crops of Sikkim. The analyses in present study showed the variations in the area, production and productivity of four major crops viz. paddy, maize, ginger and large cardamom during 2003-2015. There has been a shift from cereals to cash crops in the state as evident from the decline in the areas of both maize and paddy and increasing area of ginger. The large cardamom still occupies the second position in area after the maize and influencing the agrarian economy of the state of Sikkim. Recent constraints in terms of pest and disease incidences, nutritional deficiencies factors and inadequate management practices have hampered the cardamom production. This calls for policy intervention as well as strengthening of extension services to the large cardamom growers as the large cardamom crop has the potential of providing double income to the farmers as compared to the others crops.

\section{References}

Agriculture Contingency Plan for District: North, East, South, West Sikkim (2012). http://www.kiran. nic. in/ pdf/ contingency_plan1/Sikkim/SKM3-

SouthSikkim-30.10.12.pdf

Agriculture statistics at a Glance (2014) Ministry of Agriculture, Government of India, Published in India Oxford University press.

Bisht, V. K., Negi, A. K. and Bhandari, A. K. (2011). Ammomum subulatum 
cardamom: Traditional Phytochemical and Biological Activities - An overview, African Journal of Agriculture Research, 8(24): 53885390.

Comprehensive progress report (2014). Sikkim Organic Mission Strategic

DESME (2002).Department of Economics, Statistics, Monitoring and Evaluation Sikkim: A Statistical Profile 2002. Gangtok, India: DESME, Government of Sikkim.

DESME (2005). Department of Economics, Statistics, Monitoring and Evaluation Sikkim: A Statistical Profile 2005. Gangtok, India: DESME, Government of Sikkim.

DESME (2006). Department of Economics, Statistics, Monitoring and Evaluation State Economic Census, Gangtok, India: DESME, Government of Sikkim.

DESME (2010). Department of Economics, Statistics, Monitoring and Evaluation Sikkim: A Statistical Profile 2009-10. Gangtok, Sikkim: DESME, Government of Sikkim.

Economic Survey of Sikkim (2006-07).

FSADD (2010-11). Annual progress Report, Food Security and Agriculture Development Department Government of Sikkim.

FSADD, HCCDD (2012). Food Supply and Agriculture Development Department, Horticulture and Cash Crop Development Department "Sikkim towards Fully Organic State by 2015". Govt. of Sikkim

FSADD, HCDD (2012). Food Security and Agriculture Development Department, Horticulture and Cash Crop Development Department. Sikkim Towards

FSADD/ HCDD (2003-04). Annual progress report, Food Security and Agriculture Development Department Horticulture and Cash Crops Development
Department, Government of Sikkim.

HCDD (2007-08). Annual Report, Horticulture and Cash Crop Development Department, Government of Sikkim, District Agriculture PlanGovt. of Sikkim.

HCDD (2012-13). Annual Report, Horticulture and Cash Crops Development Department, Government of Sikkim.

Maitra, A. (2007). Cardamom-The queen of spices. http://www.bolokids.com/index. $\mathrm{cfm} ? \mathrm{md}=$ Content $\& \mathrm{sd}=$ Articles \&Article $\mathrm{ID}=18$

NEC (2002). North Eastern Council, Basic Statistics of North Eastern Region 2002. North Eastern Council, Shillong.

Portel, B. k. (2015). Economics of organic cash crops and food crops in Sikkim: a comparative study. Department of Economics school of Social Science, Sikkim University. $6^{\mathrm{TH}}$ Mile, Samdur, Tadong, Gangtok, Sikkim, India

Rahman, H., Bujarbaruah K.M., Srivastava L.S., Karuppaiyan R., Avasthe R.K. and Singh M. (2007). Status Of Ginger Cultivation In Sikkim With Special Reference To Disease Management, ICAR Research Complex for NEH Region Sikkim Centre, Tadong, Gangtok-737 10 https://www.researchgate.net/publicatio n/309135819

Research and Extension plan of East Sikkim (2006). http://kvkeastsikkim. nic.in/About_KVK/ profile_sikkim.htm Sharma, E., Sharma, R., Singh, K., and Sharma G. (2000). A boon for mountain populations: Large Cardamom farming in the Sikkim Himalaya, Mountain Research and Development, 20(2): 108111.

Sharma, S. (1999). Large Cardamom Cultivation: A Real Contribution to Village Economy, M.A thesis, Central Department of Economics, Tribhuvan 
University, Kirtipur, Kathmandu, Nepal Sikkim Organic Mission (2014). Comprehensive progress report http:// www. Sikkim organic mission.gov.in/wp content /uploads /2015 /01/C omprehensive-report.pdf

Sikkim: A Statistical Journal (2013).Government of Sikkim, Department of Economics, Statistics, Monitoring and Evaluation. Land utilization Statistics of Sikkim for 199596, Agriculture Department, Govt. of Sikkim.
Sikkimnow.blogsspot.in (2014) Auction conducted by NERAMAC Ltd.

SOM/ Sikkim Organic Mission (2014). Comprehensive Progress Report 2014: Sikkim Organic Mission. Tadong, India: Sikkim Organic Mission, Government of Sikkim.

www.sikkim stat.com

Yadav, S. (2013) Cardamom cultivation, its effect in rural livelihoods and its importance in international market, University I Nor land.

\section{How to cite this article:}

Smriti Subba and Souvik Ghosh. 2017. Status of Large Cardamom (Amomum subulatum) among the Major Crops in Sikkim. Int.J.Curr.Microbiol.App.Sci. 6(11): 166-175. doi: https://doi.org/10.20546/ijcmas.2017.611.021 